\title{
Ideological pluralism of Eugene O'Neill examined by LAVINIA
}

\author{
Qingyu YANG \\ Jiyuan Vocational and Technical College \\ Jiyuan, 454650 China
}

\begin{abstract}
This article from "Mourning Becomes Electra" heroine LAVINIA analysis, clarifies Nietzsche, Freud thought in this image reflected the body, to state thought of $O^{\prime}$ Neill is particular, complex, broad and profound. Nietzsche's main rebel influence is from Christianity, and the pursuit of capitalist civilization contempt for individual liberation of Dionysian spirit advocated. Freud's main influence is the psychological structure and the "unconscious" theory, "Oedipus complex" and "Electra complex." Lao Tzu's influence is mainly reflected in the "reverted to its roots," "against the war" and "desire tranquility" three areas. LAVINIA unique "This one," is thinking of Eugene O'Neill • eclectic art crystallization.
\end{abstract}

Keywords- LAVINIA; • Eugene O'Neill; Nietzsche; Freud

\section{INTRODUCTION}

Eugene O'Neill, "the father of American drama" known, won the Nobel Prize for Literature in 1936. The idea is multi-source complex, broad and deep, it is not only by the ill-fated experience, family love and hate, the social impact of drastic changes, and another important reason is that he is good at standing on the shoulders of the great masters, learning their thinking nutrition essence. He drew rich nourishment from Kropotkin, Schopenhauer, Nietzsche, Marx, Freud, Jung, I, Shakespeare, Strindberg, Ibsen. He inherited their predecessors, and the development of their predecessors, eclectic, and thus become an independent. "Mourning Becomes Electra" is Eugene • O'Neill's masterpiece, it is the author of ink LAVINIA most main characters, and it is the only one throughout the trilogy's main characters, the paper is cut from the characters, by Nietzsche, Freud and I thought the body reflects that how O'Neill analyze eclectic and form one combination.

\section{EUGENE O'NEILL AND NIETZSCHE}

Nietzsche, the 19th century philosopher Ye Deguo half, advocated the will to power and superhuman philosophy that the highest goal of life is to seek the will's power, and the decline of civilization will need to have the supreme power of the "Superman" to save. He declared that God is dead, called smashed idols, and he got rid of the stale tradition, was against capitalist civilization, and pursued individual liberation, advocated unrestrained Dionysian spirit. O'Neill Nietzsche is described as extremely worship. Nietzsche's influence on O'Neill's is mainly in the following three aspects.

Rebellion against Christianity, throughout Nietzsche is anti-Christian fighters. His cries of "God is dead", tremors are throughout the 20th century. He proposed revaluation of all values, as opposed to oppressive religion of humanity, which provoked a strong resonance in O'Neal. In "Mourning Becomes Electra", the O'Neill Puritan moral hypocrisy were deeply exposed and criticized. Puritan moral hypocrisy suppressed people's emotions, people should advocate abstinence, love is shameless, and instinct is a sin, so this should be turned into a living person aircraft machine without feelings. O'Neal with tit for tat, and unequivocally affirmed the role of emotions. In "Mourning Becomes Electra", it is precisely because repressed emotions do not stretch. Twist metamorphosis led to the tragic Mengnan family tragedy. LAVINIA also eager beautiful love, but because the character of Puritanism ingredients suppressed her emotions, this should be the prime of twenty-three she has become stiff, dry sound, without a trace of feminine charm, of course, no mother Cleveland Augustine is as full of vitality, so it does not get the love of all ages. So strong love turned into hate, making her Puritan moralist morality, and moral hypocrisy used the sword to kill Bo Lante, Klee Augustine and Olin. These are blood O'Neill Puritan ethics complaints. When the island trip LAVINIA completed her liberation, her body plump up, humanity was filling up, she became a lover of life, and has become the mother of his daughter. But she is the source of family tragedy, and committed too many sins, for peace of mind, and only selfpunishment, they bear their own sins and family.

Contempt is for the pursuit of personal liberation and capitalist civilization. Nietzsche tendency of capitalist civilization and humanity repressed a profound criticism that the liberation of the human personality is much more important than the human pursuit of material. O'Neill also believes that indulging in possession of wealth is a direct factor leading to the spirit of the fallen man. This idea of LAVINIA also has a significant manifestation. LAVINIA is a typical individual liberation of suitors, as the Black Avenger to her, because the pursuit of individual liberation is blocked, thereby distorting perverted mind. LAVINIA chose the grave like mansion as their destination, which reflects his contempt for capitalist civilization. As the sole successor family, she has dreamed of something and someone else has a huge wealth and prominent position. However, she has chosen to self-confinement, throw flowers, and shut the doors and windows, cut off all contacts with the outside world, which in itself is crazy to only focus on the pursuit of wealth, she was ignoring the rebellious spirit of the pursuit of capitalist civilization. Moreover, the reason why self LAVINIA confinement is realized that he can not forget the love of Porlant. She is as a rich girl, the father is the mayor, 
the general, the largest shipping company owner, Adam Salim - Bolan Te is a merely small captain, his parents died, and he is of no fixed abode, he wandered around. This relationship can be described as the door does not properly account, while LAVINIA loves him so deeply, even though he has passed away, loves are still in the depths of the unconscious LAVINIA and occupy the most important position, indicating that she is light substances and heavy emotion.

\section{FREUD AND EUGENE O'NEILL}

Sigmund Freud is the founder of the Austrian psychologist, psychoanalysis, and Marx, Einstein, together known as the influence of three great Jewish world. Freud's theory is an important concept which is "unconscious," he says that the psychological structure of consciousness is very small, just the tip of the iceberg, and the boundless expanse unconscious, is hidden in underwater iceberg and it is difficult to detect the vast majority of people. Like a bite full of unconscious impulses cauldron of passion, if not its uncontrolled or uncontrollable, let blatant form or disguise the expansion, it is like opening a Pandora's box, which caused pain and suffering. When Floyd in the United States during transmission, it is the peak of O'Neill creation, he naturally influenced Freud.

O'Neal Freud is affected by the most typical example which is his masterpiece, "Mourning Becomes Electra", meaning the play's title is "Mourn-ing Becomes Electra", meaning that the initiator is a strong "Electra plot "the LAVINIA. LAVINIA had filled with love, love father Ai Sila, Captain Bo Lante love, love Peter, love brother Olin. However, due to the Puritan morality, her loves blocked are not free flowing. Because I love my father unethical, Aibulante another big rival is mother, then when his mother is in infighting, there is state of life and death, hatred in the hearts of the bud grows. LAVINIA is not a stick to moral person, but it is a very powerful man, a good use of moral restraint is to attacking others, in order to achieve their ulterior purpose of man. She is the daughter of his father's name, they use the sword of moral intimidation "conquest," the mother of Christine Augustine wanted to force her to submit to the Puritan morality, she does not enjoy the sweetness of love, never wants to be in the tomb-like mansion. When Cleveland Augustine moral revolt snare, poison Ai Sila - Mengnan eloped with Porlant when she is exposed politician style, deliberately gave a Christenfeld's try opportunities and took advantage of Olin love jealous heart, let Olin witnessed all of this, by Olin hand, he hated and killed her but honestly loved the Bolan Te, he is also stifled Cleveland Augustine life, resulting in Cleveland Augustine suicidal despair. This battle, LAVINIA described it as a great success. However, the mask of morality can not extinguish the passion, she is longing for love within the heart, eager and happy. So the rival has to go, which is no longer used as a weapon of moral situation, she has become a "mother's daughter." After the line of the island, she wore colorful costumes, experience the beautiful love, madly pursued happiness. That $\mathrm{O}^{\prime} \mathrm{Neal}$ affected Freud is no doubt, but O'Neill is absorbed criticism of Freud's views. From the ideological content, he said he does not think "Libido" is the driving force of all human behavior, but that is the root of modern disease of old God of death, as well as science and pragmatism unable to provide a new God, to meet the people who remained in the primitive religion instinct - to find the meaning of life, to comfort the fear of death instinct. He believes that it embodies the contradiction between the human spirit and the pursuit of material gain, the Protestant ethic for humanity is repressed, for large-scale industrial production and other aspects of human alienation. Formally speaking, Floyd is a psychologist, he will find simplified formulas for psychological, and O'Neill is a writer, he will find the evolution of tearing the heart of the plot.

\section{LAO AND EUGENE O'NEILL}

Laozi, the late Spring and Autumn people, surnamed Li, name Er, the word Dan, was the founder of Taoism School. Its main idea is contained in five thousand words "moral", the core philosophy of Lao Tzu is the "Road", although his "Road" have free will, but it is "no way" "not proper name". The idea is full of the most valuable speculative philosophy of dialectic thinking that everything has not only against each other, they are interdependent, both positive and negative aspects are into each other, and he put forward "Counter - Moving" proposition. In the social ideal of fraud it was selfish to be greed and hated, depicting a "Gan its food, its own service, security of their home, their folk music, Utopia screen". Advocate "ascetic" calling back "small country with few people" living conditions. Laozi's influences on O'Neill are mainly in the following three aspects.

Laozi reverted to its roots of "moral" once the "Road" is interpreted as "independent and not be changed, but not perilous weeks", "Counter - Moving", "Big said death, death, saying far, far away, saying reversed. "That is to say, things are always in flux, and movement is along a certain direction, the result is often the opposite direction changes. Laozi promoted the rule of celestial bodies, which is used to refer to the general rule change things. In his view, worldly things rise and fall, success, growth and maturity are on ad infinitum, and then reverted to its roots. This idea is the core of Taoist thought, in LAVINIA there is a clear manifestation of the body. LAVINIA moment is "Father's Daughter", who said: "I love my father more than anyone in the world who are powerful, in order to protect him from harm, whatever I'm willing to do" while claiming to be the mother of his daughter, "From now on, I told you blow up, you did not hear? I am my mother's daughter, and not one of you! No matter how you like, I want to live!" while dressing in silence, while they wearing gorgeous. While a guard Tao, there is maintenance Puritan morality, maintaining family honor. While he is a daughter of nature, as long as love, he is just happy. Moment was disowned Avengers, instigation Olin killed his lover Bo Lante, forced his mother committing suicide, and cause the death sentence for his brother. While he is a savior to carry the cross, abandoned beautiful love, throw flowers, closed shutters, jealously guarding the tomblike Mengnan mansion to bear the sins of the whole family, save the decline of the family. Above opposites is into each 
other constantly, Laozi typically embodies "Counter Moving" view. Moreover, she is the only survivor of the family, and her direction is the direction of future Mengnan family. The play's other characters are yearning to live a secluded island life, and everyone has their own dream island. This is actually emigrated, out of a desire Mengnan family. LAVINIA island life is also very yearning, longing for the freedom of love. But in the end she was returning to their roots, jealously guarding Mengnan house, reflecting the impact of O'Neal reverted formed by Laozi's thought of its roots.

Craving craving quiet serenity is one of the dominant ideology of Lao Tzu, in his "moral" in Chapter XVI clearly states: "Induce xujing, keep quiet Benedict" He believes that the human heart could have been open quiet, just because of their selfishness and the desire to make the outside world in turmoil, in order to hold the peace of mind of nature, it only causes false keep quiet. In the social ideal, he advocate "small country" utopian social ideals. O'Neal also desire a quiet life, , he traveled, came to China in 1929, to "seek peace and quiet and tranquility," and hopes dashed when he left for Honolulu, he said: "If I can not find where it is still quiet and peaceful, then even have to go to the South Pole, I expense. "In mourning Becomes Electra ", the idea of pursuing a peaceful O'Neill prominently is reflected in the imagery of the island. LAVINIA dreamed many times on the island, which is to get rid of the secular disputes, obtain a peaceful and pure life. LAVINIA have personally been to the island, she loved the island, it is as one could desire to spend his life on the island. Life on the island is no contamination by modern civilization, where life is aesthetic, is intoxicating. Although grief short life, there's dancing and singing in harmony, but not secular struggle for power and killing each other.

\section{CONCLUSIONS}

This desire for a peaceful ideal O'Neill is largely affected by the Laozi. This is the Eugene O'Neill, an eclectic person, a synthesizer, a pioneering innovator. He has aptly likened himself to a furnace, fusion hundred, only as a case; he was also a busy bee, honey harvest of flowers, which led to a unique "This one," of course, it is complicated, "this one" perhaps is O'Neill's charm, and for the charm of all the masters!

\section{References}

[1] $\mathrm{J} \cdot$ Gould modern American playwright $[\mathrm{M}]$. New York: New Press, 1966.56.

[2] Arthur and Barbara Gelb • Gelb O'Neill pass [M]. New York: New Press, 1973.121.

[3] Eugene O'Neill's Mourning Becomes Electra - [M] Shanghai: Shanghai Literature and Art Publishing House, 1982,44

[4] Yang Hongru. Reread Laozi[M] Chengdu: Sichuan People's Publishing House, 1997.216,216,201,191.

[5] Chen Qinghui. Straight solution of Chuangzi and Laozi [M] Hangzhou: Zhejiang Arts Publishing House, 1998, 6. 